\title{
The role of argon plasma coagulation in the management of Barrett's esophagus: a single-center experience
}

This article was published in the following Dove Press journal:

Gastrointestinal Cancer:Targets and Therapy

2I April 201 I

Number of times this article has been viewed

\section{Yahia Z Gad'}

Adel A Zeid ${ }^{2}$

'Associate Professor of Internal Medicine, Mansoura Specialized Medical Hospital, Mansoura University, Mansoura, Egypt; ${ }^{2}$ Consultant Surgeon, Al Nil Hospital, Mansaura, Egypt
Correspondence: Yahia Zakaria Gad Mansoura Specialized Medical Hospital, Mansoura University, Mansoura, Egypt Tel +20 I2 758 II 50

Email yahiazgad@yahoo.com
Background/aim: Patients with Barrett's esophagus (BE) are 30 times more likely to develop esophageal adenocarcinoma (EAC) than the general population. Data regarding the use of argon plasma coagulation (APC) for treatment of patients with BE in Egypt are still limited. This article discusses the efficacy and safety of APC as a thermoablative modality in Egyptian patients with BE.

Materials and methods: A total of 73 referred eligible patients with a confirmed endoscopic and histopathologic diagnosis of BE were enrolled in this study and subjected to thermoablation by high-power (hp)-APC equipment at a $60 \mathrm{~W}$ setting until complete ablation or a maximum of five sessions and were followed up clinically and endoscopically at 3-month intervals. Computergenerated randomization allocated patients into APC-treated and control groups $(n=75)$, all of whom were treated with a proton pump inhibitor.

Results: Minor and major complications occurred in 8 of 73 (10.95\%) and 1 of 73 (1.36\%) patients, respectively. Macroscopic ablation was achieved after one session in 37 of $73(50.63 \%)$ patients, and complete histologic ablation was confirmed after 167 sessions in 69 of $73(94.52 \%)$ patients. At 1-year follow-up, no relapses of BE or progression to EAC were observed.

Conclusion: hp-APC at a medium-energy setting of $60 \mathrm{~W}$ in an acid-reduced environment can ablate BE effectively and safely with promising initial results.

Keywords: Barrett's esophagus, argon plasma coagulation

\section{Introduction}

Barrett's esophagus (BE) is a complication of gastroesophageal reflux disease, in which the normal squamous epithelium of the lower segment of the esophagus is replaced by columnar epithelium with specialized intestinal metaplasia. Histologically, it is characterized by the existence of goblet cells. ${ }^{1,2}$ Metaplasia is followed by a series of histopathologic changes, namely dysplasia and carcinoma in situ, and finally leading to the development of esophageal adenocarcinoma (EAC), as documented by follow-up studies in areas with high cancer incidence. ${ }^{3,4}$ As a premalignant condition, patients with $\mathrm{BE}$ are 30 times more likely to develop EAC than the general population. ${ }^{5,6}$ Several endoscopic ablative techniques to destroy the metaplastic esophageal columnar epithelium have been used, including thermal laser photocoagulation, endoscopic mucosal resection, photodynamic therapy, and argon plasma coagulation (APC). ${ }^{7,8}$ In a reduced acid environment, the injured squamous epithelium usually recovers. Data regarding the use of APC on patients with BE in Egypt are still limited. 
The aim of the research was to study the efficacy and safety of APC as an ablative modality in Egyptian patients with BE.

\section{Materials and methods}

A total of $73 \mathrm{BE}$ patients referred to the endoscopy unit at Mansoura Specialized Medical Hospital from January 2007 to December 2010 were enrolled in the study after giving written, well-informed consent. The inclusion criterion was confirmed endoscopic and histopathologic diagnosis of BE. Exclusion criteria were the inability to co-operate, give a written consent, or return for follow-up; age less than 18 years or more than 80 years; pregnancy, lactation, or nonuse of birth control measures; prior antireflux surgery, any esophageal or gastric operation (such as esophagectomy, gastrectomy, fundoplication, Billrith I or II operation, any vagal manipulation); the presence of esophageal varices; the presence of any uncontrolled comorbidities; a known allergy or intolerance to proton pump inhibitors (PPIs); allergy to coumarins or heparin; an inability to discontinue nonsteroidal anti-inflammatory drugs during the study period; uncontrolled coagulopathy; international normalized ratio (INR) $>1.3$ times control or platelet count $<50,000 / \mathrm{mm}$; and the presence of histopathologic evidence of EAC or high-grade dyplasia of the esophagus in the past or on screening examination.

All eligible patients underwent a thorough history and physical examination. Laboratory tests included complete blood picture, platelet count, prothrombin time, INR, partial thromboplastin time, and a urine pregnancy test for women in the childbearing period. Control of the enrolled patients' symptoms was ensured by a 6-week course of an oral PPI. Then, diagnostic upper endoscopy was performed by a single operator using Pentax ${ }^{\circledR}$ (EG-2901; Pentax Corporation, Tokyo, Japan). Patients with endoscopic evidence of erosive esophagitis were sent for retreatment with a higher dose of a PPI for another month. Instillation of $7 \mathrm{~mL}$ of $2 \%$ Lugol's solution was given through the biopsy channel of the endoscope from the squamocolumnar channel to the lower third of the esophagus. This chromoendoscopic technique stains the normal esophageal mucosa dark brown or greenish brown while the Barrett mucosa remains unstained.

The following endoscopic landmarks were recorded in centimeters from the central incisor teeth using the markings on the used endoscope during pull-back: the proximal most squamocolumnar junction (Z-line), including Barrett's islands; gastroesophageal junction (GEJ); and diaphragmatic constriction. Biopsy specimens of the Barrett's segments were taken per standardized surveillance protocol by using large cup "jumbo" forceps with a cup open diameter of $8 \mathrm{~mm}$ and a central needle. Two initial biopsy specimens were taken $1 \mathrm{~cm}$ distal to the GEJ with the endoscope retroverted in the stomach. Then, fourquadrant biopsies were obtained at least every $2 \mathrm{~cm}$ from the GEJ proximal to the squamocolumnar junction by using a turn-in technique. Additional biopsy specimens were taken from any "target" lesion, such as nodule, polyp, or ulcer in the Barrett's segment. All biopsy specimens were fixed in formalin and were processed, sectioned, and interpreted in a single laboratory by a single pathologist. The slides were stained with hematoxylin and eosin as well as Alcian blue at a $\mathrm{pH}$ level of 2.5. The diagnosis of BE was defined by the presence of intestinal metaplasia in the specimen taken proximal to the GEJ. Dysplasia was defined as the presence of neoplastic epithelium confined within the basement membrane in the absence of inflammation and was classified as negative for dysplasia, low-grade dysplasia, high-grade dysplasia, and carcinoma.

Endoscopic therapy was carried out with the patients under sedoanalgesic medications (midazolam $10 \mathrm{mg}$ and/or meperidine $25-100 \mathrm{mg}$ intravenously). Topical pharyngeal anesthesia with xylocaine spray was given initially. To control esophageal peristaltic contractions during the procedure, an antispasmodic was sometimes given.

The high-pressure (hp)-APC equipment included an axial APC probe (diameter $2.3 \mathrm{~mm}$ ), an argon gas source, and a high-frequency surgical unit (VIO 300 D with APC2, Erbe Elektromedizin, Tubingen, Germany). The argon gas flow was set at $1.5-2 \mathrm{~L} /$ minute as recommended by the manufacturers for clinical application. The power setting was adjusted in relation to the relative risk of perforation at the site of local APC application. APC was applied until a visible white coagulum appeared at a power setting of $60 \mathrm{~W}$ and a forced mode with a pulse rate of 16/second. Ablation was initiated at the gastroesophageal transition zone, defined as the end of the gastric folds and the beginning of the tubular esophageal epithelium, and proceeded proximally to the squamocolumnar junction in a longitudinally brush-like stroke fashion. In long-segment BE, the procedure was limited to $50 \%$ of the whole circumference to reduce the risk of esophageal stricturing. Endoscopic treatment sessions were continued until a total of five sessions was reached or endoscopic BE was no longer evident. 
During endoscopy, for minimal air insufflations, there was frequent suctioning of excess gas and air to prevent intestinal distension and reduce the risk of perforation.

For the retrospective analysis of complications related to APC, odynophagia, chest pain, and fever were considered minor complications. On the other hand, bleeding, perforation, and esophageal stenosis were defined as major complications.

After the procedure, patients were admitted to the gastroenterology inpatient ward and received a twice-daily PPI. Any procedure-related symptoms were recorded. After 3 days, patients were discharged on a high-dose PPI for 3 months until complete ablation. Follow-up endoscopies and four-quadrant biopsies were done at 3-month intervals with recording of the local endoscopic findings. All control group patients $(n=75)$ were treated with high-dose oral PPIs for 3 months.

\section{Statistical analysis}

Comparative analysis was done using unpaired Student's $t$-test for continuous variables and $\chi^{2}$ test for categorical variables. All tests were two-tailed. $P$ values $<0.05$ were considered significant. Statistical tests were performed using SPSS Version 17.0 (SPSS Inc., Chicago, IL) or Microsoft Excel (Microsoft, Redmond, DC).

\section{Results}

From a total of 237 referred patients with a documented diagnosis of $\mathrm{BE}$, only 148 patients met the inclusion criteria and were randomized to thermoablation by APC plus highdose PPI therapy $(n=73)$ and medical therapy alone as a control group $(n=75)$. As shown in Table 1 , there were no significant statistical differences between the two groups regarding demographic and baseline clinical data.

For the thermoablation group, a total of 167 sessions (range one to three) were performed for all patients. Minor and major complications occurred in 8 of $73(10.95 \%)$ and 1 of $73(1.36 \%)$ patients, respectively, while the control group showed no side effects related to the medications used, as shown in Table 2. No perforation, strictures, or other major complications were reported. These complications occurred in 17 of $167(10.17 \%)$ sessions for minor complications and 1 of $167(0.59 \%)$ sessions (an APC-related minor bleeding episode was treated with a local norepinephrine injection). A significant positive correlation was observed between the initial length of $\mathrm{BE}$ and the number of thermoablative sessions $(\mathrm{r}=0.67, P$ value $=0.003)$ across all patients enrolled .
Table I Demographic and endoscopic data of the studied groups $^{\mathrm{a}}$

\begin{tabular}{|c|c|c|}
\hline Parameters & $\begin{array}{l}\text { Thermoablation } \\
\text { group }(n=73)\end{array}$ & $\begin{array}{l}\text { Control } \\
\text { group }(n=75)\end{array}$ \\
\hline Age (years) & $28-59$ & $27-61$ \\
\hline Gender (M:F) & $38: 35$ & $39: 36$ \\
\hline Tobacco use & $36(49.31 \%)$ & 37 (49.33\%) \\
\hline NSAID use & $33(45.2 \%)$ & 35 (47.94\%) \\
\hline Spicy food & 27 (36.98\%) & 29 (38.66\%) \\
\hline $\begin{array}{l}\text { Duration of GERD } \\
\text { symptoms (years); } \\
\text { mean } \pm S D\end{array}$ & $3 \pm 1.2$ & $4 \pm 0.8$ \\
\hline $\begin{array}{l}\text { Duration since } \\
\text { diagnosis of } B E \text { (years); } \\
\text { mean } \pm S D\end{array}$ & $3 \pm 1.1$ & $2.5 \pm 0.9$ \\
\hline $\begin{array}{l}\text { Median duration of } \\
\text { follow-up (months) }\end{array}$ & $12(10-14)$ & $12(11-13)$ \\
\hline $\begin{array}{l}\text { First-degree relatives } \\
\text { with } \mathrm{Gl} \text { cancer }\end{array}$ & $4(5.47 \%)$ & $4(5.33 \%)$ \\
\hline $\begin{array}{l}\text { Days per week with } \\
\text { GERD symptoms; } \\
\text { mean } \pm \text { SD }\end{array}$ & $5 \pm 2$ & $4 \pm 2$ \\
\hline BMI $\left(\mathrm{kg} / \mathrm{m}^{2}\right)$ & $27 \pm 1.1$ & $26.9 \pm 1.4$ \\
\hline Hiatal hernia (n) & 7 (9.58\%) & $8(10.66 \%)$ \\
\hline $\begin{array}{l}\text { Hiatal hernia length } \\
(\mathrm{cm}) \text {; mean } \pm S D\end{array}$ & $3.5 \pm 1.7$ & $3.4 \pm 1.5$ \\
\hline $\begin{array}{l}\text { BE segment length } \\
(\mathrm{cm}) ; \text { mean } \pm S D\end{array}$ & $2.4(1.3-4.3)$ & $2.3(1.7-4.2)$ \\
\hline Histopathology of BE & & \\
\hline No dysplasia & 72 (98.64\%) & 74 (98.67) \\
\hline Low-grade dysplasia & I (I.36\%) & I (I.33\%) \\
\hline
\end{tabular}

Note: ${ }^{2}$ No statistically significant differences were observed between the studied groups.

Abbreviations: BE, Barrett's esophagus; BMl, body mass index; F, female; GERD, gastroesophageal reflux disease; GI, gastrointestinal; M, male; NSAID, nonsteroidal anti-inflammatory drug; SD, standard deviation.

Macroscopic ablation was achieved after one session in 37 of 73 (50.63\%) patients, and complete histologic ablation was confirmed after 167 sessions in 69 of 73 (94.52\%) patients, as shown in Table 3.

Buried glands were detected in 2 of 69 (2.89\%) patients with complete thermoablation. Two and four additional sessions were sufficient to eradicate the buried glands and to complete $100 \%$ histologic regression, respectively, in the thermoablation group, reaching a total of $173 \mathrm{hp}-\mathrm{APC}$ sessions.

At 1-year follow-up, no relapses of $\mathrm{BE}$ or progression to EAC were observed in patients who had complete thermoablation.

Histologic ablation was defined by the microscopic absence of specialized intestinal metaplasia above or at GEJ, including those found beneath the neosquamous epithelium. 
Table 2 Patients' complaints before and after therapy in the studied groups

\begin{tabular}{lll}
\hline Parameters & $\begin{array}{l}\text { Thermoablation } \\
\text { group }(\mathbf{n}=\mathbf{7 3})\end{array}$ & $\begin{array}{l}\text { Control group } \\
(\mathbf{n}=\mathbf{7 5})\end{array}$ \\
\hline $\begin{array}{l}\text { Before therapy } \\
\text { Upper abdominal }\end{array}$ & $59(80.82 \%)^{\mathrm{a}}$ & $6 \mathrm{I}(81.33 \%)$ \\
$\begin{array}{l}\text { pain } \\
\text { Odynophagia or } \\
\text { dysphagia }\end{array}$ & $34(46.57 \%)^{\mathrm{a}}$ & $35(46.66 \%)$ \\
$\begin{array}{l}\text { Retrosternal } \\
\text { soreness }\end{array}$ & $47(64.38 \%)^{\mathrm{a}}$ & $49(65.33 \%)$ \\
$\begin{array}{l}\text { After therapy } \\
\text { Fever }\end{array}$ & $\mathrm{I}(\mathrm{I} .36 \%)$ & \\
$\begin{array}{l}\text { Mild bleeding } \\
\text { Retrosternal pain } \\
\text { and/or soreness }\end{array}$ & $\mathrm{I}(\mathrm{I} .36 \%)$ & 0 \\
$\begin{array}{l}\text { Epigastric fullness } \\
\text { and/discomfort }\end{array}$ & $4(5.11 \%)$ & 0 \\
\hline
\end{tabular}

Note: ${ }^{2}$ No statistically significant differences were observed between the studied groups.

\section{Discussion}

For patients with BE, life-long surveillance endoscopy is recommended because of an increased risk for developing dysplasia and EAC. ${ }^{9}$ The intestinal metaplasia of BE is thought to arise from abnormal cell differentiation after injury caused by acid reflux. It is thought that the putative esophageal stem cells can undergo differentiation in a normal pathway to squamous epithelium in a normal or reduced acid environment after epithelial cell reinjury. ${ }^{10}$ The aim of thermal reinjury in this work, therefore, is reversal of $\mathrm{BE}$ and elimination of EAC.

APC is noncontact thermal tissue coagulation in which the argon gas provides the medium for the delivery of an electric current. Complete acid suppression is crucial for the regeneration of squamous epithelium. ${ }^{11}$ Coagulation

Table 3 Follow-up endoscopic findings of the two studied groups $^{\mathrm{a}}$

\begin{tabular}{lll}
\hline Parameters & $\begin{array}{l}\text { Thermoablation } \\
\text { group }(\mathbf{n}=\mathbf{7 3})\end{array}$ & $\begin{array}{l}\text { Control group } \\
(\mathbf{n}=\mathbf{7 5})\end{array}$ \\
\hline $\begin{array}{l}\text { Endoscopic regression } \\
\text { Complete after first session }\end{array}$ & $\begin{array}{l}37 / 73(50.63 \%) \\
\text { Complete after }\end{array}$ & 0 \\
$\begin{array}{l}73 / 73(100 \%) \\
\text { finishing sessions }\end{array}$ & 0 \\
$\begin{array}{l}\text { Histologic } \\
\text { regression complete }\end{array}$ & $69 / 73(94.52 \%)$ & 0 \\
$\begin{array}{l}\text { Partial } \\
\text { Buried glands }\end{array}$ & $4 / 73(5.48 \%)$ & $2(2.66 \%)$ \\
$\begin{array}{l}\text { Progress to } \\
\text { adenocarcinoma }\end{array}$ & $2 / 69(2.89 \%)$ & 0 \\
\hline
\end{tabular}

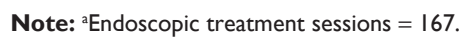

depth achieved by APC is described to be a function of the power setting, the duration of application, and the distance from the target tissue. ${ }^{12}$ The popular power setting of APC varies from $30 \mathrm{~W}$ to $90 \mathrm{~W}$. The tissue effect of high power settings regarding depth and diameter of electrocoagulation is associated with a higher complication rate during clinical application. ${ }^{13}$ In this work, the power setting used was $60 \mathrm{~W}$, as preferred in our center and well adopted by our senior consultants when managing nonmalignant esophageal lesions.

Several prospective randomized trials have studied the ablative endoscopic methods of $\mathrm{BE}$ with variable eradication rates $(72 \%-100 \%) .{ }^{14-16}$ Comparing APC with placebo, the ablation rate of BE was statistically significant versus the control group $(63 \%$ and $15 \%)(P<0.001) .{ }^{17}$ In this work, the histopathologically documented ablation rate was 69 of $73(94.52 \%)$ with superior initial results to the standard APC.

High-dose PPI therapy alone has resulted in the development of islands of squamous-appearing epithelium within the Barrett's segments. ${ }^{18,19}$ Intestinal metaplasia underneath these islands has been described in as many as $38.5 \%$ of the biopsy samples and nonimpressive changes in the mean length of the Barrett's mucosa. ${ }^{18,20}$

In this work, partial regression was observed in 4 of $73(5.48 \%)$ patients in the studied thermoablation group and 2 of $75(2.66 \%)$ patients in the control group. According to the previous data, ${ }^{18-20}$ this histologic regression is unreliable and warrants regular surveillance endoscopy of what is going on in the latter group and further consideration of additional ablative sessions to ensure complete histopathologic ablation for the former group. An additional four sessions were needed only for the patients to reach their target without reported complications.

In comparison with the standard APC systems, the VIO APC device offers a larger power range (10-120 W), and the tissue effect of this hp-APC equipment concerning depth and diameter of tissue coagulation would be expected to be higher, causing significant complications. In reports of previous use of APC for the ablation of neoplastic and nonneoplastic BE, minor side effects have been reported in up to $54.5 \%$ of patients, and major complications have been observed in 3\%-9.6\% of cases. ${ }^{13,21}$

Using a medium-energy setting of $60 \mathrm{~W}$, hp-APC equipment results in a low rate of side effects $(11.7 \%)$ and major complications $(0.9 \%) .{ }^{21}$ Complications may result from tissue contact coagulation when the probe tip is too close to the 
targeted tissue surface. ${ }^{22}$ In this work, minor complications occurred in 8 of $73(10.95 \%)$ patients, and only 1 of 73 $(1.36 \%)$ patients suffered major complications in the form of a minor bleeding episode. This was treated with a local vasoconstrictor injection through the endoscopy biopsy channel. Otherwise, no other serious early or late complications during 1-year follow-up were reported. These data reveal an encouraging safety profile of hp-APC equipment at this setting when safety regulations are followed.

A drawback of the ablation therapies is persistent columnar epithelium beneath the neosquamous epithelium. The higher the power, with its deep thermal effect, the lesser the incidence of columnar glands with intestinal metaplasia buried under the neosquamous epithelium and the higher the incidence of complications. ${ }^{23,24}$

In the present work, with medium-energy (60 W) hpAPC, buried glands were observed in 2 of $69(2.89 \%)$ patients, and two additional sessions were sufficient for eradication.

The incidence of relapse of BE after APC thermoablative therapy was studied with variable results. The best results were reported with short-term follow-up in patients who achieved complete ablation. ${ }^{25}$

Data from the present work confirm previous reports that the "pulse 2" mode can be used for the treatment of lesions where a large area of tissue penetration is required with great safety and efficacy for treatment of BE with or without intraepithelial neoplasia. ${ }^{21}$ Moreover, as a thermoablative therapy, APC could overcome missed residual small foci of high-grade dysplasia or carcinoma in situ that if progressed would account for treatment failures in many endoscopic therapies. ${ }^{26}$

In this work, after 1-year follow-up, regular endoscopic evaluation of studied patients revealed neither macroscopic nor histopathologic relapse. However, long-lasting thermoablative effects are to be determined on long-term follow-up.

\section{Conclusion}

Our data revealed that hp-APC at a medium-energy setting of $60 \mathrm{~W}$ in an acid-reduced environment can ablate BE effectively and safely with promising initial results. Surveillance endoscopy is still advocated in such patients in order to detect possible relapses of $\mathrm{BE}$ and/or other early neoplastic lesions of EAC.

\section{Disclosure}

The authors report no conflicts of interest in this work.

\section{References}

1. Slehria S, Sharma P. Barrett's esophagus. Curr Opin Gastroenterol. 2003;19:387-393.

2. Gerson I, Shelter K, Triadafilopoulos G. Prevalence of Barrett's esophagus in asymptomatic individuals. Gastroenterology. 2002;123: 461-464.

3. Montgomery E, Bronner M, Goldblum J. Reproducibility of the diagnosis of dysplasia in Barrett's esophagus. Human Pathol. 2001;32: 368-378.

4. Saek J, Hiroshi MD, Kimura A. Biologic and clinical significance of squamous epithelial metaplasia of the esophagus. Surgery. 2002;131(1): S22-S27.

5. Solaymani-Dodaran M, Logan RF, West J, et al. Risk of esophageal cancer in Barrett's esophagus and esophageal reflux. Gut. 2004;53: 1070-1074.

6. Kosuri K, Jankowski J. Adenocarcinoma in Barrett's esophagus, too common, too fatal, and still too badly managed. J Clin Gastroenterol. 2007;41:S129-S134.

7. Montes CG, Brandalise NA, Deliza R, et al. Antireflux surgery followed by bipolar elactrocoagulation in the treatment of Barrett's esophagus. Gastrointest Endosc. 1999;50:173-177.

8. Sampliner RE, Faigel D, Fennerty MB, et al. Effective and safe endoscpic reversal of nondysplastic Barrett's esophagus with thermal electrocoagulation combined with high dose acid inhibition: a multicenter study. Gastrointest Endosc. 2001;53:554-558.

9. David EF, Bergein FO, Virender KS, et al. Endoscopic ablation of Barrett's esophagus: a multicenter study with 2.5-year follow-up. Gastrointest Endosc. 2008;68:867-876.

10. Samplinger RF, Fennerty MB, Garewal HS. Revarsal of Barrett's esophagus with acid suppression and multipolar electrocoagulation: preliminary results. Gastrointest Endosc. 1996;44:532-535.

11. Rodriguez SA, Adler DG, Chand B, et al. Mucosal ablation devices. Gastrointest Endosc. 2008;68:1031-1042.

12. Watson JP, Bennett MK, Griffin SM, Mattewson K. The tissue effect of argon plasma coagulation on esophageal and gastric mucosa. Gastrointest Endosc. 2000:52:342-345.

13. Manner H, May A, Faerber M, Ell C. The effect of argon plasma coagulation on porcine liver tissue using the new VIO system in comparison to APC 300 and Nd:YAG laser. Digestive Disease Weak, 14-19 May, 2005. Gastrointest Endosc. 2005;61:233.

14. Pinotti AC, Cecconello I, Filho FM, et al. Endoscopic ablation of Barrett's esophagus using argon plasma photocoagulation: a prospective study after fundoplication. Dis Esophagus. 2004;17: 243-246.

15. Pagani M, Granelli P, Chella B, et al. A Barrett's esophagus: combined treatment using argon plasma photocoagulation and entireflux surgery. Dis Esophagus. 2003;16:279-283.

16. Faybush AM, Sampliger RE. Randomized treatment in Barrett's esophagus. Dis Esophagus. 2003;18:291-297.

17. Ackroyd R, Tam W, Schoeman M, et al. Prospective randomized controlled trial of argon plasma photocoagulation versus endoscopic surveillance of patients with Barrett's esophagus after antireflux surgery. Gastrointest Endosc. 2004;39:1-7.

18. Gore S, Healy C, Sutton R, et al. Regression of columnar lined epithelium (Barrett's) esophagus with continuous omeprazole therapy. Alimen Pharmacol Ther. 1993; 7:274-228.

19. Neuman CS, Iqbal TH, Cooper BT. Long term continuous omeprazole treatment in patients with Barrett's esophagus. Alimen Pharmacol Ther. 1995;9:451-454.

20. Sharma P, Morales TG, Bhattacharyya A, et al. Squamous islands in Barrett's esophagus: what lies beneath? Am J Gastroenterol. 1998;93:332-335.

21. Manner H, May A, Faerber M, et al. Safety and efficacy of a new high power argon plasma photocoagulation system (hp-APC) in lesions of the upper gastrointestinal tract. Dig Liver Dis. 2006;83:471-478. 
22. Zhang L, Dong L, Liu J, et al. Endoscopic ablation of Barrett's esophagus using the second generation argon plasma photocoagulation: a prospective randomized controlled trial. JNMU. 2009;23(3): 183-188.

23. Malick KJ. Clinical applications of argon plasma photocoagulation in endoscopy. Gastroenterol Nurs. 2006;29:386-391.

24. Deviere J. Argon plasma photocoagulation therapy for ablation of Barrett's esophagus. Gut. 2000;51:763-764.
25. Basu KK, Pick B, West KP, deCaestecker JS. Efficacy and one year follow up of argon plasma photocoagulation therapy for ablation of Barrett's esophagus: factors predicting persistence and recurrence of Barrett's epithelium. Gut. 2002;51;776-780.

26. Schemre DB, Huang JL, Lin OS, Cantone N. Treatment of Barrett's esophagus with early neoplasia: a comparison of endoscopic therapy and esophagectomy. Gastrointest Endosc. 2008:67(4):595-601.

\section{Publish your work in this journal}

Gastrointestinal Cancer: Targets and Therapy is an international, peer-reviewed, open access journal focusing on gastro-intestinal cancer research, identification of therapeutic targets and the optimal use of preventative and integrated treatment interventions to achieve improved outcomes, enhanced survival and quality of life for the cancer patient. The manuscript management system is completely online and includes a very quick and fair peer-review system. Visit http://www.dovepress.com/testimonials.php to read real quotes from published authors.

Submit your manuscript here: http://www.dovepress.com/gastro-intestinal-cancer-targets-and-therapy-journal 